THE CRITICAL ROLE OF MARKETS IN CLIMATE CHANGE ADAPTATION

\author{
Sarah E. Anderson \\ Terry L. Anderson \\ Alice C. Hill \\ Matthew E. Kahn \\ Howard Kunreuther \\ Gary D. Libecap \\ Hari Mantripragada \\ Pierre Mérel \\ Andrew Plantinga \\ V. Kerry Smith \\ Working Paper 24645 \\ http://www.nber.org/papers/w24645
}

\author{
NATIONAL BUREAU OF ECONOMIC RESEARCH \\ 1050 Massachusetts Avenue \\ Cambridge, MA 02138 \\ May 2018
}

The authors thank the Koret Foundation for funding a conference on climate change adaptation through market responses at the Hoover Institution, Stanford. The views expressed herein are those of the authors and do not necessarily reflect the views of the National Bureau of Economic Research.

At least one co-author has disclosed a financial relationship of potential relevance for this research. Further information is available online at http://www.nber.org/papers/w24645.ack

NBER working papers are circulated for discussion and comment purposes. They have not been peer-reviewed or been subject to the review by the NBER Board of Directors that accompanies official NBER publications.

(C) 2018 by Sarah E. Anderson, Terry L. Anderson, Alice C. Hill, Matthew E. Kahn, Howard Kunreuther, Gary D. Libecap, Hari Mantripragada, Pierre Mérel, Andrew Plantinga, and V. Kerry Smith. All rights reserved. Short sections of text, not to exceed two paragraphs, may be quoted without explicit permission provided that full credit, including () notice, is given to the source. 
The Critical Role of Markets in Climate Change Adaptation

Sarah E. Anderson, Terry L. Anderson, Alice C. Hill, Matthew E. Kahn, Howard Kunreuther, Gary D. Libecap, Hari Mantripragada, Pierre Mérel, Andrew Plantinga, and V. Kerry Smith

NBER Working Paper No. 24645

May 2018

JEL No. Q1,Q15,Q21,Q22,Q24,Q25,Q28,Q51,Q54,R14

\section{ABSTRACT}

This paper summarizes and synthesizes the role of markets in facilitating climate change adaptation. It explains how market signals encourage adaptation through land markets. It also identifies impediments to critical market signals, provides related policy recommendations, and points to promising new technologies. Urban, coastal, and agricultural land markets provide effective signals of the emerging costs of climate change. These signals encourage adjustments by both private owners and by policy officials in taking preemptive action to reduce costs. In agriculture, they promote consideration of new cropping and tillage practices, seed types, timing, and location of production. They also stimulate use of new irrigation technologies. In urban areas, they motivate new housing construction, elevation, and location away from harm. They channel more efficient use of water and its application to parks and other green areas to make urban settings more desirable with higher temperatures. To be effective, however, land markets must reflect multiple traders and prices must be free to adjust. Where these conditions are not met, land market signals will be inhibited and market-driven adaptation will be reduced. Because public policy is driven by constituent demands, it may not be a remedy. The evidence of the National Flood Insurance Program and federal wildfire response illustrates how politically difficult it may be to adjust programs to be more adaptive.

Sarah E. Anderson

University of California, Santa Barbara

Bren School of Environmental Science

and Management \& Department of

Political Science

4510 Bren Hall

Santa Barbara, CA 93106

sanderson@bren.ucsb.edu

Terry L. Anderson

Hoover Institution

269 E. Hodgeman Rd

Bozeman, MT 59718

terryleeanderson@gmail.com

Alice C. Hill

Hoover Institution

Stanford University

Palo Alto, CA

ahill2@stanford.edu

Matthew E. Kahn

Department of Economics

University of Southern California

KAP

Los Angeles, CA 90089

and NBER

kahnme@usc.edu
Howard Kunreuther

Operations and Information Management

The Wharton School

University of Pennsylvania 3730 Walnut

Street, $500 \mathrm{JMHH}$

Philadelphia, PA 19104-6366 and NBER

kunreuther@wharton.upenn.edu

Gary D. Libecap

Bren School of Environmental Science

and Management and Economics Department

University of California, Santa Barbara

Bren Hall 4412

Santa Barbara, CA 93106-5131

and NBER

glibecap@bren.ucsb.edu

Hari Mantripragada

Civil Engineering

University of Pittsburgh

Pittsburgh, PA

ham103@pitt.edu 
Pierre Mérel

University of California, Davis

Agricultural and Resource Economics

3102 Social Sciences and Humanities

Davis, CA 95616

merel@primal.ucdavis.edu

Andrew Plantinga

Bren School of Environmental Science

and Management

University of California

Rm 3424

Santa Barbara, CA 93106

plantinga@bren.ucsb.edu

V. Kerry Smith

Department of Economics

W.P. Carey School of Business

P.O. Box 879801

Arizona State University

Tempe, AZ 85287-9801

and NBER

kerry.smith@asu.edu 


\title{
The Critical Role of Markets in Climate Change Adaptation
}

\author{
by
}

Sarah Anderson, UCSB; Terry L. Anderson, Hoover; Alice C. Hill, Hoover; Matthew E. Kahn, USC and NBER; Howard Kunreuther, U Penn and NBER; Gary D. Libecap, UCSB and NBER; Hari Mantripragada, Pitt; Pierre Mérel, UCD; Andrew Plantinga, UCSB; and V. Kerry Smith, ASU and NBER

May 16, 2018

"Climate change, once considered an issue for a distant future has moved firmly into the present"(Melillo, et al, 2014). ${ }^{1}$ Humanity must find expeditious ways to deal with its effects, including more extreme heat and precipitation events, sea-level rise, higher intensity storms, and extended drought. The most widely discussed option to address anthropogenic climate change is thru mitigation. Policies to reduce emissions include taxing carbon, trading carbon credits, and displacing conventional sources of energy by subsidizing renewable technologies. To be globally effective, these mitigation options require international collective action that has been difficult to attain (Libecap, 2014). ${ }^{2}$ Moreover, even with full implementation of cross-national mitigation options, such as through the Paris Agreement of 2015, recent estimates suggest that the temperature targets will be missed unless emissions are more sharply reduced. ${ }^{3}$

Ambitious mitigation efforts undertaken now do not alter the fact that humans are committed to some amount of climate change as the result of past emissions (Mauritsen and Pincus, 2017). ${ }^{4}$ As such, adaptation will necessarily be part of the response to climate change. Adaptation can "moderate or avoid harm or exploit beneficial opportunities" associated with

\footnotetext{
${ }^{1}$ Melillo, J. M., Richmond, T.C. and Yohe, G.W. eds., 2014: "Climate Change Impacts in the United States: The Third National Climate Assessment." U.S. Global Change Research Program, 841 pp. doi:10.7930/J0Z31WJ2.

${ }^{2}$ Libecap, G. D. 2014, “Addressing Global Environmental Externalities: Transaction Costs Considerations,” Journal of Economic Literature 52 (2): 424-479.

${ }^{3} \mathrm{https}: / /$ www.metoffice.gov.uk/news/releases/2018/decadal-forecast-2018.

${ }^{4}$ Mauritsen, T. and Yohe, R. 2017. “Committed Warming Inferred from Observations." Nature Climate Change 7: 652-655.
} 
climate change. ${ }^{5}$ Adaptation has some distinctive advantages. In addition to adaptation undertaken by private individuals or firms, adaptation policies can be implemented and adjusted unilaterally by countries without requiring international coordination. A country's adaptive responses offer opportunities for learning. They can serve as templates for use elsewhere. Social scientists have published peer-reviewed scholarship highlighting successful examples of adaptation in North America (Filho and Keenan, 2017), ${ }^{6}$ central Europe (Rüter, et al, 2014), ${ }^{7}$ and South America (Krellenberg and Barth, 2014) ${ }^{8}$ There also are examples of maladaptation in the Maldives, Ethiopia, South Africa, and Bangladesh (Magnan, et al, 2016). ${ }^{9}$

Whether and to what extent humans will adapt to a changing climate depends partially on whether they receive sufficient advance information about the possible impacts of new weather patterns resulting from this change. Moreover, if climate change affects goods traded in markets, the prices of these goods will change, sending signals to owners, traders, and policy makers of the anticipated impacts. These incentives create opportunities to respond and with them identify potential benefits from adaptation. A market does not require consensus on climate change outcomes, and indeed is most effective when there are multiple and perhaps, conflicting, views. Accordingly, market prices will incorporate new information as it unfolds. In this manner, a

\footnotetext{
${ }^{5}$ http://www.ipcc.ch/pdf/assessment-report/ar5/wg2/ar5_wgII_spm_en.pdf, p. 6.

${ }^{6}$ Filho, L.W. and Keenan, J. 2017. Climate Change Adaptation in North America: Fostering Resilience and the Regional Capacity to Adapt. New York: Springer. Accessed December 22, 2017. http://www.springer.com/us/book/9783319537412.

${ }^{7}$ Rüter, S., Vos, C. C., van Eupen, M., and Rühmkorf, H. 2014. "Transboundary ecological networks as an adaptation strategy to climate change: The example of the Dutch - German border." Basic and Applied Ecology 15 (8): 639-650. Accessed December 22, 2017. https://doi.org/10.1016/j.baae.2014.09.007.

${ }^{8}$ Krellenberg, K. and Barth, K. 2014. "Inter- and Transdisciplinary Research for Planning Climate Change Adaptation Responses: The Example of Santiago de Chile." Interdisciplinary Science Reviews 39 (4): 360-375. Accessed December 22, 2017. http://www.tandfonline.com/doi/full/10.1179/0308018814Z.00000000097. ${ }_{9}^{9}$ Magnan, A. K., Schipper, E. L. F., Burkett, M., Bharwani, S., Burton, I., Eriksen, S., Gemenne, F., Schaar, J., and Ziervogel, G. 2016. "Addressing the risk of maladaptation to climate change." WIREs: Climate Change 7 (5): 646665. Accessed December 22, 2017. http://onlinelibrary.wiley.com/doi/10.1002/wcc.409/abstract;jsessionid=DA101B5F581DEB4EC1719DA3951A66B 4.f01t04.
} 
market can reveal new evidence regarding the anticipated effects of a changing climate. ${ }^{10}$ This knowledge, in turn, becomes valuable in responding in a timely and cost-effective manner. On the other hand, policies that inhibit trade or that fix prices can, as a result, undermine this information revelation process and impede adaptation.

To explore the conditions under which adaptation can take place, a workshop on the potential for market-based responses to climate change involving 10 economists, political scientists, civil engineers, and policy scholars was held at the Hoover Institution, Stanford University, November 7-8, 2017. Building upon the contributions presented at the workshop and the discussions that ensued, this paper explains how market signals encourage adaptation through land markets. It also identifies impediments to critical market signals, provides related policy recommendations, and points to promising new technologies. ${ }^{11}$

\section{Market Signals Can Stimulate Adaptation}

Agricultural and Urban Land Markets

Land is perhaps the foremost resource signaling climate change. Because land is a durable asset and a primary input in agricultural production, urban housing, and commercial development, climate change will affect its productivity and desirability. If land is traded in markets, these effects will be capitalized into land values, thus signaling anticipated impacts and

\footnotetext{
${ }^{10}$ Grossman S.J. and Stiglitz J.E. (1976). "Information and Competitive Price Systems." The American Economic Review. 66(2):246-53.

${ }^{11}$ Workshop on adaptation funded by the Koret Foundation. Participants include Andrew Plantinga, "Land Markets and Climate Change Adaptation," Pierre Mérel, "Measuring Market-Mediated Adaptation to Climate Change in US Agriculture: Empirical Evidence and Challenges," Matthew E. Kahn, "Urban Climate Change and Local Real Estate Markets," Gary Libecap, "Adaptation to Climate Change: The Role of Water Markets," Matthew E. Kahn and V. Kerry Smith, "Reforming the National Flood Insurance Program as Adaptation to Climate Change," Alice C. Hill and Bill Kakenmaster, "A Tale of Two Cities: A Comparative Analysis of Miami Beach, FL and Norfolk, VA and Lessons in Coastal Real Estate Markets," Howard Kunreuther, "Encouraging Adaptation to Flood Risk: The Role of the National Flood Insurance Program," Sarah Anderson, Ryan Bart, Maureen Kennedy, Andrew MacDonald, Max Moritz, Andrew Plantinga, Christina Taque, and Matthew Wibbenmeyer, "Salience-driven Responses to Climate Change and their Consequences for (Mal)Adaptation, and Hari Mantripragada, "Feasibility Analysis of Coal-based Power with $\mathrm{CO} 2$ Control."
} 
the potential benefits of adaptation. As land is generally fixed in supply, the value of land derives from changes in demand. The demand for land in a variety of uses reflects both current and expected future returns, monetary or non-monetary, to the goods and services it provides (Lobell, et al, 2011). ${ }^{12}$ Climate change may affect land productivity through temperature variation, access to water and rainfall (Jaeger, et al), ${ }^{13}$ and desirability for human habitation (Albouy, et al, 2016). ${ }^{14}$ New risk assessments recognizing climate change affect these attributes and as a result land prices, thereby motivating landowners to adjust land use (Severen et al. 2018)..$^{15}$

Identifying changes in land market prices that are tied to new climate change risks is challenging statistically because it is difficult to know if a given change in risk is due to climate change or to background variation in climate. Even so, a large quantitative literature exists on how variables affecting productivity and desirability influence land values (Plantinga, 2017). The observed price patterns in response to long term weather patterns provide evidence on how land markets likely will respond to evolving climate change information (Irwin, 2002; Anderson and West, 2006; Burke and Emerick, 2016; McWilliams and Moore, 2017). ${ }^{16}$

\footnotetext{
12 Lobell, D. B., Schlenker, W., and Costa-Roberts, J. (2011). Climate Trends and Global Crop Production Since 1980. Science, 333(6042):616-620.

${ }^{13}$ Jaeger, W. K., Amos, A., Bigelow, D., Chang, H., Conklin, D., Haggerty, R., Langpap, C., Moore, K., Mote, P., Nolin, A., Plantinga, A. J., Schwartz, C., Tullos, D., and Turner, D. (2017). Scarcity amid abundance: Water, climate change, and policy role of regional system models. Proceedings of the National Academy of Sciences 114(45):11884-9.

${ }^{14}$ Albouy, D., Graf, W., Kellogg, R., and Wolff, H. (2016). Climate amenities, climate change, and American quality of life. Journal of the Association of Environmental and Resource Economists, 3, 205-246.

${ }^{15}$ Severen, C., Costello, C., and Deschenes, O. (2018). "A Forward Looking Ricardian Approach: Do Land Markets Capitalize Climate Change Forecasts?" Journal of Environmental Economics and Management, forthcoming.

${ }^{16}$ Irwin, E. G. (2002). "The Effects of Open Space on Residential Property Values." Land Economics, 78,465-480; Anderson, S. T. and West, S. E. (2006). "Open Space, Residential Property Values, and Spatial Context." Regional Science and Urban Economics, 36, 773-789; Burke, M. and Emerick, K. (2016). "Adaptation to Climate Change: Evidence from US Agriculture.” American Economic Journal: Economic Policy, 8, 106-140. McWilliams, M. R. and Moore, M. R. (2017). "Land-Use Adaptation to Climate Change in the United States, 1982-2012." Technical report, University of Michigan.
} 
For example, empirical evidence reveals how uncertainty over future land rents and changes in the incidence of natural disasters influences both agricultural and urban land values (Plantinga et al, 2002; Bin and Landry, 2013). ${ }^{17}$ There also is strong evidence that climate change forecasts are capitalized into farmland prices and the effect is larger where there is greater awareness of future climate change risk as revealed in public opinion surveys (Severen, et al, 2016). Jaeger et al, (2017) find that farm land rents, crop choice, and irrigation decisions in the Willamette Valley of Oregon vary with temperature and precipitation. Landowners make adjustments to higher temperatures and less precipitation by changing crops and irrigation practices as well as by shifting across forest, agriculture, and urban land uses. Additionally, vineyard sales data in California and Oregon analyzed by Beasley and Cross (2017) indicate that climate forecasts raise land values in cool, but not in warm areas. The finding suggests that the market is anticipating that already-warm vineyard areas will become less productive in the future as temperatures increase and wine production will gradually move to cooler regions. ${ }^{18}$

Absent adaptive responses in agriculture, recent empirical studies indicate large, negative short-run effects on crop yields, channeled principally through increases in crop exposure to extreme heat and reduced access to water (Fisher et al., 2012; Lobell et al., 2011; Porter et al., 2014). ${ }^{19}$ Holding everything constant, by the end of the century area-weighted average yields of

\footnotetext{
${ }^{17}$ Plantinga, A. J., Lubowski, R. N., and Stavins, R. N. (2002). "The Effects of Potential Land Development on Agricultural Land Prices. Journal of Urban Economics, 52, 561-581.

${ }^{18}$ Beasley, J. and Cross, R. (2017). “Are Vineyard Buyers Warming Up to Cooler Locations?” Oregon State University, Technical report.

${ }^{19}$ Fisher, A. C., Hanemann, W. M., Roberts, M. J., and Schlenker, W. (2012). “The Economic Impacts of Climate Change: Evidence from Agricultural Output and Random Fluctuations in Weather: Comment." The American Economic Review, 102(7):3749-3760; Porter, J. R., Xie, L., Challinor, A. J., Cochrane, K., Howden, S. M., Iqbal, M. M., Lobell, D. B., and Travasso, M. I. (2014). "Food Security and Food Production Systems.” In Field, C. B., Barros, V. R., Dokken, D. J., Mach, K. J., Mastrandrea, M. D., Bilir, T. E., Chatterjee, M., Ebi, K. L., Estrada, Y. O., Genova, R. C., Girma, B., Kissel, E. S., Levy, A. N., MacCracken, S., Mastrandrea, P. R., and White, L. L., eds., Climate Change 2014: Impacts, Adaptation, and Vulnerability. Part A: Global and Sectoral Aspects. Contribution of Working Group II to the Fifth Assessment Report of the Intergovernmental Panel on Climate Change, pages 485-533. Cambridge University Press, Cambridge, United Kingdom and New York, NY, USA.
} 
corn, soybeans, and cotton could decrease by $63-82 \%$, leading to a decline in U.S. farmland prices between $27 \%$ and $69 \%$ (Schlenker and Roberts 2009, Schlenker et al, 2006). ${ }^{20}$ Such productivity declines would be gradually reflected in land market prices as production moves to less affected areas and crops.

Adaptation via land market signals and related agricultural adjustments, however, could modify these negative predictions substantially. Adaptation could occur through geographic shifts in farm production as well as shifts in crop timing, crop mixes, and hybridization. Warming would likely increase the useful growing season in some areas, often limited by spring and fall frost events, which could allow farmers to adjust planting times to reduce heat exposure during summer months or allow multiple cropping (Seifert and Lobell, 2015). ${ }^{21}$ Earlier planting by around two weeks could reduce US corn yield losses due to warming by $44 \%$ (Ortiz-Bobea and Just, 2013). ${ }^{22}$ Deryng et al (2011) use global crop models for corn, soybeans, and spring wheat and find that shifts in planting dates and cultivation could more than compensate for yield losses induced by climate change in temperate regions. ${ }^{23}$ Research and development is also an important source of adaptation. New hybrid corn varieties that were both higher-yielding and more robust to heat exposure increased yields markedly following the Dust Bowl years until about 1960 (Roberts and Schlenker, 2011). Further evidence of climate adaptation can be seen

\footnotetext{
${ }^{20}$ Schlenker, W., and Roberts, M. J. (2009). Nonlinear Temperature Effects Indicate Severe Damages to US crop Yields under Climate Change. Proceedings of the National Academy of Sciences, 106(37): 15594-15598; Schlenker, W., Hanemann, W. M., and Fisher, A. C. (2006). "The Impact of Global Warming on U.S. Agriculture: An Econometric Analysis of Optimal Growing Conditions.” The Review of Economics and Statistics, 88(1):113-125.

${ }^{21}$ Seifert, C. A., and Lobell, D. B. (2015). Response of Double Cropping Suitability to Climate Change in the United States. Environmental Research Letters, 10(2): 024002.

${ }^{22}$ Ortiz-Bobea, A. and Just, R. E. (2013). Modeling the Structure of Adaptation in Climate Change Impact Assessment. American Journal of Agricultural Economics, 95(2):244-251.

${ }^{23}$ Deryng, D., Sacks, W. J., Barford, C. C., and Ramankutty, N. (2011). Simulating the Effects of Climate and Agricultural Management Practices on Global Crop Yield.” Global Biogeochemical Cycles, 25(2). Costinot, A., Donaldson, D., and Smith, C. (2016). "Evolving Comparative Advantage and the Impact of Climate Change in Agricultural Markets: Evidence from 1.7 Million Fields Around the World." Journal of Political Economy, 124(1):205-248.
} 
during the westward expansion of American agriculture in the $19^{\text {th }}$ century when farmers introduced crop varieties suited to more arid and both colder and warmer climates (Olmstead and Rhode, 2011). ${ }^{24}$

Absent any adaptation, Gammans et al. (2017) predict a 21.0\% decline in winter wheat yield, a $17.3 \%$ decline in winter barley yield, and a 33.6\% decline in spring barley yield for French agriculture by the end of the century. These predictions, however, hold technology and cropping practices constant. If farmers adjust, then the costs can be reduced. In fact, French farmers appear to have partially adjusted by increasing the share of winter barley relative to spring barley, as winter barley is more resistant to higher temperatures. Continuing technology trends in these crops would counterbalance most of the negative effects of climate change, even without accounting for climate-change-induced research and development. ${ }^{25}$

Other empirical evidence also indicates that farmers worldwide are responsive to changes in weather risk. For instance, panel data from 1956-1990 analyzed by Taraz (2018) reveal that Indian farmers adapt irrigation investments and cropping patterns to shifting Monsoon regimes. ${ }^{26}$ Producers in Israel substitute capital, primarily irrigation technology, for a poorer climatic conditions (Fleischer, et al, 2011). ${ }^{27}$ Using panel data from 1982-2010, across wet and dry years in parts of Colorado dependent upon precipitation, Manning et al (2011) found that farmers have responded to expected surface water shortages by reducing acres of corn planted and concentrating the application of scarce water on productive areas to protect yields. The authors

\footnotetext{
${ }^{24}$ Olmstead, A. L. and Rhode, P.W. (2011). "Adapting North American Wheat Production to climatic challenges, 1839-2009." Proceedings of the National Academy of Sciences, 108(2):480-485; Waltz, E. (2014). "Beating the Heat." Nature Biotechnology, 32(7):610.

${ }^{25}$ Gammans, M., Mérel, P., and Ortiz-Bobea, A. (2017). Negative Impacts of Climate Change on Cereal Yields: Statistical Evidence from France. Environmental Research Letters, 12(5):054007.

${ }^{26}$ Taraz, V. (2018). "Adaptation to Climate Change: Historical Evidence from the Indian Monsoon.” Environmental and Development Economics.

${ }^{27}$ Fleischer, A. Mendelsohn, R. and Dinar, A. (2011) "Bundling Agricultural Technologies to Adapt to Climate Change," Technological Forecasting and Social Change 78(6): 982-90.
} 
conclude that failure to account for such behavioral adaptive responses would overstate the negative effects of climate change by $17 \% .^{28}$

Albouy et al, (2016) examine how US housing markets respond to climate amenities, such as temperature, precipitation, humidity, and sunshine, and then explore how those markets would respond to future climatic conditions and different amenities. Changes in climate amenities reduce welfare under business-as-usual climate predictions, but these losses are reduced somewhat by migration responses. Climatic effects on housing supply and demand are capitalized into urban land values (Kahn, 2017; Plantinga, 2017). Bin and Landry (2013) generally find that flood risk, often associated with climate change, is reflected in housing prices. Buyers' and sellers' risk perceptions can differ when hazard experiences are remote and risk information is incomplete, but converge in the immediate period after a flood. Risk premiums, however, appear to decline over time in the absence of any new flood event. ${ }^{29}$

\section{Water Markets}

Access to water is critical for both agricultural productivity and urban living and, hence, land values (Libecap, 2017). It will affect the ability of land owners to make the kinds of adjustments needed for agriculture and urban development. Climate change can be expected to affect both the supply and demand for freshwater though higher temperatures, greater incidence of drought, and increased use of irrigation. There also will be greater reliance upon urban green spaces, landscaping, and water for recreation as well as environmental protection (Barnett, et al. 2005 (Rosenburg, et al. 1999; Barnett, et al, 2014; Ranjan, et al. 2006; Treidel, 2012; Woodruff,

\footnotetext{
${ }^{28}$ Manning, D. T., Goemans, C., and Maas, A. (2017). "Producer Responses to Surface Water Availability and Implications for Climate Change Adaptation.” Land Economics, 93(4), 631-653.

${ }^{29}$ Bin, O. and Landry, C.E., 2013. "Changes in Implicit Flood Risk Premiums: Empirical Evidence from the Housing Market.” Journal of Environmental Economics and Management, 65(3), pp.361-376.
} 
2016). ${ }^{30}$ New supply and demand conditions require conservation, greater storage in surface reservoirs and groundwater basins, as well as supply augmentation, such as desalinization, along with reallocation from existing to new uses.

Where they exist, water markets can be a critical factor in facilitating adaptation in land markets to climate change. They can encourage reallocation of water to its highest valued uses, reflecting new demands, compensating owners of water rights, and importantly, generating information about alternative values. Information may be the single greatest contribution of water markets because successful reallocation requires that water be moved to higher-valued uses and effective supply support from water supply organizations requires weighing the costs and benefits of different options. Absent market trades, such information is not available. As suggested below, the potential of water markets in contributing to adaptation has not been "tapped."

The dominant policy response to drought, which will increase with climate change, has been government-mandated reductions in water consumption. For example, during the recent drought in California, the Governor called for $25 \%$ reductions in urban areas, along with other conservation programs. ${ }^{31}$ These uniform cutbacks, however, do not take into account different values of water use that otherwise would dictate differential reductions, and there can be

\footnotetext{
${ }^{30}$ Barnett, T., Malone, R., Pennell, W., Stammer, D., Semtner, B., and Washington, W. (2004). "The Effects of Climate Change on Water Resources in the West: Introduction and Overview." Climatic Change, 62(1-3), 1-11. https://doi.org/10.1023/B:CLIM.0000013695.21726.b8; Ranjan, S. P., Kazama, S., and Sawamoto, M. (2006). "Effects of Climate and Land Use Changes on Groundwater Resources in Coastal Aquifers. Journal of Environmental Management, 80(1), 25-35. https://doi.org/10.1016/j.jenvman.2005.08.008; Rosenberg, N. J., Epstein, D. J., Wang, D., Vail, L., Srinivasan, R., and Arnold, J. G. (1999). "Possible Impacts of Global Warming on the Hydrology of the Ogallala Aquifer Region." Climatic Change, 42(4), 677-692. https://doi.org/10.1023/A:1005424003553;Treidel, H. (Ed.). (2012). Climate Change Effects on Groundwater Resources: A Global Synthesis of Findings and Recommendations (1st edition). Boca Raton, Fla.: CRC Press; Woodruff, S. C. (2016). "Planning for an Unknowable Future: Uncertainty in Climate Change Adaptation Planning." Climatic Change, 139(3-4), 445-459. https://doi.org/10.1007/s10584-016-1822-y.

31 (www.water.ca.gov/wateruseefficiency/conservation/docs/EO_B-37-16_Report.pdf).
} 
important long-term social losses. Mandated decreases do not generate the information signals provided by markets, and there are few options for private reallocation to sustain water in critical areas. Uniform cutbacks also are not equitable since low-income consumers consume less water per capita than do high-income consumers. In contrast, shifting water prices that reflect new supply and demand conditions promote voluntary adaptation.

Further, water markets can be used to protect minimum stream flows for environmental uses. Such acquisitions are likely more durable and consistent with the multiple values for how water is used than are government-mandated reallocations. In the latter case, water rights holders are not compensated; rights are made less secure, inhibiting water market development; and agency officials as well as lobby advocates do not have to assess the economic tradeoffs inherent in any regulatory reallocation. All of these factors suggest costly conflict and political insecurity that would undermine any conservation "set-asides." Overall, markets help answer questions about the tradeoffs that necessarily arise among irrigation, urban, industrial, and environmental uses as supplies tighten and demands increase.

Water markets exist in the fast-growing western United States, a region predicted to be especially vulnerable to climate change due to its reliance upon snow-melt (Ojha et al. 2015). ${ }^{32}$ The region has an established water rights system that allows for water to be traded. Even so, water markets are not as active as they could be. Only about $2 \%-4 \%$ of annual water consumption is traded, and there are large potential gains from reallocation from agriculture where $60-80 \%$ of water is in use (Brewer, et al, 2008).$^{33}$ Existing water prices reveal the gains from trade. For example, in Nevada's Reno/Truckee Basin, the median price of agriculture-to-

\footnotetext{
${ }^{32}$ Ojha, R, Ramadas, M, and Govindaraju. R.S. (2015), "Current and Future Challenges in Groundwater. I: Modeling and Management of Resources," Journal of Hydrologic Engineering, 20(1).

${ }^{33}$ Brewer, J, Glennon, G, Ker, A, and Libecap, G.D. (2008), "2006 Presidential Address Water Markets in the West: Prices, Trading, and Contractual Forms,” Economic Inquiry 46 (2): 91-112.
} 
urban water rights sales between 2002 and 2009 was $\$ 17,685$ /acre-foot (an acre-foot $=325,851$ gallons, about enough to meet the needs of four people for a year), whereas for agriculture-toagriculture water rights sales, the median price was $\$ 1,500 /$ acre-foot, a difference in value of over 12 times (Libecap, 2011) ${ }^{34}$ Despite these differences, a major reason for limited market trading during drought is a costly, slow, and resistant regulatory process where multiple parties can intervene to protest water trades (Culp, et al, 2014). ${ }^{35}$

The information provided by access to the pricing information from water trades can serve is essential for water supply organizations as they tackle climate change. Further, required water supply estimates conducted by urban water supply organizations often hold existing demand constant, but that would not be the case if urban water were priced more effectively. Many urban water suppliers use flat rates that do not encourage conservation. ${ }^{36} \mathrm{~A}$ few cities, however, use steep tiered water pricing, whereby low levels of consumption are priced near zero, but rates rapidly increase as consumption rises. Tucson, Arizona uses such tiered pricing, whereas similar cities near Phoenix use low flat rate or modest tiered pricing systems. Per-capita consumption in Tucson is about $25 \%$ less than in Phoenix. ${ }^{37}$ Such pricing policies can be designed to be both equitable and effective in encouraging conservation. It is possible to protect essential family water consumption with minimal or "lifeline" prices, allowing prices for water use beyond that threshold to rise.

\section{Policy Flexibility Can Encourage Adaptation}

\footnotetext{
${ }^{34}$ Libecap, G.D. (2011), "Institutional Path Dependence in Climate Adaptation: Coman's "Some Unsettled Problems of Irrigation," American Economic Review 101 (1): 112-40.

${ }^{35}$ Culp, P.W., Glennon, R.J., and Libecap, G.D., 2014, Shopping for Water: How the Market can Mitigate Water Shortages in the American West. Washington D.C.: Island Press.

${ }^{36} \mathrm{http} / / / \mathrm{www}$.circleofblue.org/waterpricing/

${ }^{37}$ ww.tucsonsentinalcom/local/report/050214 water/tucson-water-rates-higher-than-phx-usage-lower-here.
} 
Adaptation requires access to the latest information on the possible timing, intensity, and location of climate change effects. Regulations that restrict market trades or reduce the incentive to engage in them limit the potential of land markets to promote adaptation to climate change. The evidence suggests that farmers can be responsive across a variety of margins through shifts in cropping, timing, cultivation, water use, and location. Their incentives to do so, however, can be reduced by subsidized crop insurance and unpriced irrigation water that reduces the private costs of lower productivity due to weather risk (Wahl, 1989; Annan and Schlenker, 2015). ${ }^{38}$ Restrictions on land use and cropping adjustments, such as those adopted under the Conservation Reserve Program, also can limit flexible responses (Antle and Capalbo, 2010). ${ }^{39}$ Further, the failure to define property rights to groundwater leaves it vulnerable to over extraction as farmers turn to groundwater during drought (Ayres, et al, 2018). ${ }^{40}$ Government and private research and development promoted by strengthened intellectual property policies also are essential for discovery of new production techniques, capital, and crop varieties.

Land use regulations that restrict market trades and subsidies that artificially encourage particular types of uses can distort the information released and make responses to new information less flexible. For instance, zoning and growth controls are often motivated by desirable objectives. They seek to influence urban development and to preserve open space. Nevertheless, these controls constrain land market transactions and hence, distort property prices. Accordingly, where in place, zoning restrictions can limit the generation of useful price signals

\footnotetext{
${ }^{38}$ Wahl, R.W. (1989). Markets for Federal Water: Subsidies, Property Rights, and the Bureau of Reclamation. Washington D.C.: Resources for the Future; Annan, F. and Schlenker, W. (2015). "Federal Crop Insurance and the Disincentive to Adapt to Extreme Heat." The American Economic Review, 105(5):262-266.

${ }^{39}$ Antle, J. M. and Capalbo, S. M. (2010). "Adaptation of Agricultural and Food Systems to Climate Change: An Economic and Policy Perspective.” Applied Economic Perspectives and Policy, 32(3):386-416.

${ }^{40}$ Ayres, A.B, Edwards, E.C., and Libecap, G.D. "How Transaction Costs Obstruct Collective Action:

The Case of California's Groundwater," NBER Working paper.
} 
and the associated incentives for adaptive land use in light of new climate change forecasts (Glaeser, et al, 2005; Dempsey and Plantinga, 2013; Grout, et al, 2011). Accordingly, zoning rules may need to be made more flexible in order to encourage adaptive responses to climate change. Zoning maps can be redrawn to facilitate changes in land use in response to an increased threat of flooding or coastal erosion. Other land use regulations that allow for flexible adaptation, such as tradable development rights (TDRs), could be implemented more broadly. With TDRs, landowners in one area can sell development rights that permit land to be developed in another area. If the profitability of development in the receiving area were to be increased by climate change, prices for development rights would adjust and provide the correct incentives to landowners in the sending area to preserve land and for development to take place in the receiving area.

We focus, below, on flood insurance and wildfire suppression activities, which illustrate the problems at hand for land markets. They subsidize existing land uses and undermine the ability of market trades to convey information about the need to adapt to climate change.

\section{Distortions in Flood Insurance Markets and Wildfire Suppression Policies}

The National Flood Insurance Program (NFIP), enacted in 1968, provides federal subsidies to some property owners to make flood insurance rates affordable, rather than to have them reflect the risk of floods in particular locations. Under the NFIP homeowners whose houses satisfy specific criteria can be insured against flood damage at rates that are below what actuarial principles would imply. While there are provisions encouraging rate modifications, based on the base flood elevation level, in general these rates do not encourage property owners to sufficiently invest in flood-proofing measures, including moving from harm. The best signal of the changing risks in flood-prone regions is through pricing of insurance at actuarial rates, reflecting risk and adjusting them as those risks change with anticipated climate change. 
Nevertheless, the current NFIP policies encourages rebuilding in flood-prone areas. For example, the Natural Resources Defense Council reported that between 1978 and 2015 the NFIP paid $\$ 5.5$ billion to repair and rebuild more than 30,000 of the "severe repetitive loss properties" in response to flood or hurricane damage. "These homes and businesses have been rebuilt multiple times in the wake of floods or hurricanes... While they represent just 0.6 percent of the 5.1 million properties insured through the NFIP, they account for a disproportionate 9.6 percent of all damages paid, as of 2015." 41

The justification for current insurance pricing policies is to maintain rates that are "affordable" so as to increase the take-up of insurance in areas subject to flood risk. Kahn and Smith (2017) use information available from mortgage applications from 1989 to 2014 due to mandates of the Home Mortgage Disclosure Act (HMDA) and federal tax returns from 2007 to 2014 to analyze the incomes of property owners who are potential recipients of NFID-subsidized rates. Two different spatial scales are used to evaluate the income levels of households living along the coast in comparison to those who live in interior locations in each of the five Gulf Coast states. Comparing real median income for coastal counties to the same measure for interior counties, they find households in coastal areas generally have higher real median incomes and this persists over the full 25-year period.

Kahn and Smith also investigate the same question computing median income for shoreline zip codes in comparison to the adjacent interior zip codes. For Florida and Texas, the pattern is maintained, and the differences are statistically significant. For Alabama and Mississippi, the ranking of median income is maintained, but the differences in median incomes are not consistently significant. At the zip code level in Louisiana the ordering reverses, but this arises due to the

\footnotetext{
${ }^{41}$ Natural Resources Defense Council (2017), Seeking Higher Ground: How to break the Cycle of Repeated Flooding with Climate Smart Flood Insurance Reforms. Issue Brief 17-07-A, July, p. 2.
} 
locations of coastal wetlands. ${ }^{42}$ Using Internal Revenue Service (IRS) data on income distributions for those households claiming a mortgage interest deduction, median incomes estimated at the zip code level confirm the earlier HMDA results for Florida. Thus, Kahn and Smith find that NFIP pricing policy is both distorting risk signals and offering subsidized rates to higher-income households. The Congressional Budget Office's (2017) analysis of the NFIP's complex system of subsidized and cross-subsidized rates implies that $85 \%$ of the policies in the highest-risk coastal areas are below what would be implied by actuarial rates for the flood insurance rate maps associated with these areas. ${ }^{43}$

Affordability in this context has been interpreted as providing insurance at rates below actuarial levels for those living in high-risk coastal areas. The size of the subsidy depends on when a home was built in relation to the most recent flood maps; whether communities are participating in public flood-risk information and mitigation programs; and other factors. It does not require an income threshold for eligibility. As a result, preferential treatments are capitalized into home values, making the prospects of dramatic changes difficult, because homeowners would then experience significant losses with any policy change.

A better signal of the changing risks in flood-prone regions is through risk-based pricing of insurance. The impact of both subsidizing higher-property values in coastal zones as well as lowering incentives to make adjustments is further revealed by Hill and Kakenmaster (2017) who examine Miami Beach, Florida and Norfolk, Virginia. Both communities underinvest in

\footnotetext{
${ }^{42}$ Coastal Protection and Restoration Authority of Louisiana (2017), Louisiana's Comprehensive Master Plan for a Sustainable Coast, State of Louisiana; Couvillion, B. R. Barras, J.A., Steyer, G.D., Sleavin, W., Fischer, M., Beck, H., Trahan, N., Griffin, B. and Heckman, D ( 2011). Land Area Change in Coastal Louisiana from 1932 to 2010, U.S. Geological Survey Scientific Investigations Map 3164, scale 1: 265,000, 12 p. pamphlet; The Data Center (2017), The Coastal Index: Tracking development of the water management cluster in Southeast Louisiana, June.

${ }^{43}$ Congressional Budget Office. 2017. The National Flood Insurance Program: Financial Soundness and Affordability (Washington, D.C.: CBO, Congress of United States, September)
} 
private and public adaptation to sea-level rise. Of the two communities, Miami Beach has much higher land values, supported in part by underpricing flood risk. Outdated flood maps do not reflect future hazards and in both areas there is investment in new development driven by tax subsidies.

The lack of household preparation for high-cost, but low-probability events, such as major flood and wildfire disasters is explored by Kunreuther (in press). ${ }^{44}$ Individuals exhibit a set of systemic biases such as myopia (focusing on short-time horizons when appraising protective measures), optimism (underestimating the likelihood of a loss before it occurs) and simplification (focusing on the low probability prior to the event and treating it as below their threshold level of concern). To encourage individuals to purchase insurance and invest in protective measures prior to a disaster, Meyer and Kunreuther (2017) recommend a behavioral risk audit that uses the principles of choice architecture coupled with economic incentives. ${ }^{45}$

These individual biases, including attention to low-probability, high-cost events only in the short-term after they are experienced, also result in government investment that is maladaptive (Anderson, et al. forthcoming). ${ }^{46}$ Wibbenmeyer, et al. (2018) report that governments allocate more fire prevention resources to communities that have experienced a recent wildfire than to otherwise similar communities that have not experienced a fire, resulting in misallocation of resources to communities that likely have a lower risk of wildfire. ${ }^{47}$ Similarly, historical government responses to flooding have included construction of infrastructure such as

\footnotetext{
${ }^{44}$ Kunreuther, H. (in press) Opportunities and Challenges in Reauthorizing the National Flood Insurance Program Behavioral Public Policy.

${ }^{45}$ Meyer, R., and H. Kunreuther (2017), The Ostrich Paradox: Why We Underprepare for Disasters. Wharton Digital Press.

${ }^{46}$ Anderson, S.E., Bart, R.R., Kennedy, M.C., MacDonald, A.J., Moritz, M.A., Plantinga, A.J., Tague, C.L. and Wibbenmeyer M. (forthcoming). "The Dangers of Disaster-Driven Responses to Climate Change." Nature Climate Change.

${ }^{47}$ Wibbenmeyer, M., Anderson, S.E., and Plantinga, A.J. (2018) "Salience and the Government Provision of Public Goods". Available at SSRN: https://papers.ssrn.com/sol3/papers.cfm?abstract_id=3173855
} 
levees that have worsened subsequent flooding downstream (Day et al. 2007, Pinter 2008, Kundzewicz, et al, 2013).$^{48}$ Accordingly, for disasters such as floods and wildfires that are likely to increase with climate change, maladaptation will increase costs of climate related impacts on them.

The Options for Policy Reform Limited by Salience, Myopic Voting, and the Political Response.

The higher private costs of more stringent building standards, wildfire fuel reduction, actuarially-fair insurance rates and movement away from hazards receive push back from constituents who desire to maintain or expand existing programs. Compelled by the saliencedriven demands and myopic voting of their constituents, politicians respond by limiting policy reform and emphasizing disaster recovery rather than preparedness or adaptation (Healy and Malhotra 2009) ${ }^{49}$ By distorting prices, reacting to immediate past events, and subsidizing highincome households, policies like the NFIP and government wildfire policies that encourage resident location at the forest interface constrain effective adaptation to climate change.

\section{Adaptation through Market Signals}

Urban, coastal, and agricultural land markets provide effective signals of the emerging costs of climate change. These signals encourage adjustments by both private owners and by policy officials in taking preemptive action to reduce costs. In agriculture, they promote consideration of new cropping and tillage practices, seed types, timing, and location of production. They also stimulate use of new irrigation technologies. In urban areas, they motivate new housing construction, elevation, and location away from harm. They channel more

\footnotetext{
${ }^{48}$ Day JW Jr, Boesch D.F, Clairain E, Kemp GP, Laska S, Mitsch WJ et al. (2007) "Restoration of the Mississippi delta: lessons from Hurricanes Katrina and Rita." Science 315:1679-1684; Pinter N, Jemberie AA, Remo JWF, Heine RA, Ickes BS (2008). "Flood Trends and River Engineering on the Mississippi River System." Geophysical Research Letters 35: L23404; Kundzewicz ZW, Pinskwar I, Brakenridge GR (2013) "Large Floods in Europe, 1985-2009.” Hydrological Sciences Journal 58(1):1-7.

${ }^{49}$ Healy, A. and Malhotra, N. (2009). "Myopic Voters and Natural Disaster Policy." American Political Science Review, 103(3), 387-406.
} 
efficient use of water and its application to parks and other green areas to make urban settings more desirable with higher temperatures. To be effective, however, land markets must reflect multiple traders and prices must be free to adjust. Where these conditions are not met, land market signals will be inhibited and market-driven adaptation will be reduced. Because public policy is driven by constituent demands, it may not be a remedy. The evidence of the National Flood Insurance Program and federal wildfire response illustrates how politically difficult it may be to adjust programs to be more adaptive.

These findings suggest that specific land markets dominated by flood or wildfire risk or those on the margin of agricultural production that rely upon crop insurance to be viable may be unlikely to provide the signals needed for adaptation to climate change. These areas have welldefined constituencies and political patrons. Hence they may be more subject to political intervention to set insurance rates, maintain subsidies, and respond disproportionately to the immediate past, rather than future hazards. Unfortunately, these are precisely the areas where adaptation is most needed to prepare for and reduce the costs of climate change. More generally, land markets that are less spatially and temporally tied to specific weather-related events and constituencies may be more active in generating adaptation signals. Their broader economic base, more diverse constituencies, and multiple options for adaptation makes them more flexible in responding to the costs and opportunities generated by climate change. Other markets, such as those for energy, can also provide adaptive responses if allowed to respond to market signals generated by carbon taxes or the trading of pollution permits. These adaptations can include new technologies to reduce greenhouse gas emissions in electricity generation (Mantripragada, 2017). 